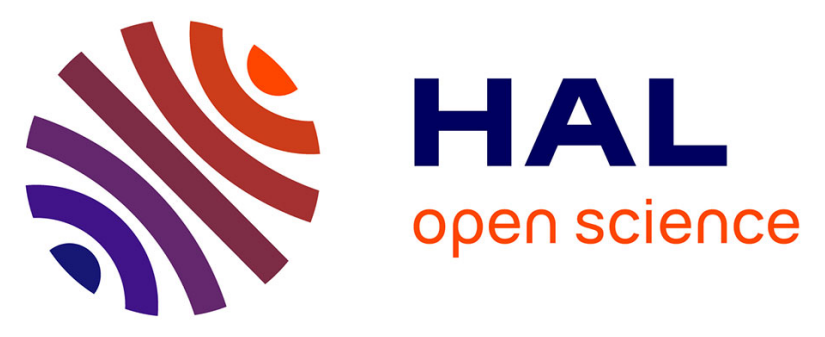

\title{
Exploring learners' perceptions of the use of digital letter games for language learning: the case of Magic Word
}

\author{
Mathieu Loiseau, Cristiana Cervini, Andrea Ceccherelli, Monica Masperi, \\ Paola Salomoni, Marco Roccetti, Antonella Valva, Francesca Bianco
}

\section{To cite this version:}

Mathieu Loiseau, Cristiana Cervini, Andrea Ceccherelli, Monica Masperi, Paola Salomoni, et al.. Exploring learners' perceptions of the use of digital letter games for language learning: the case of Magic Word. Salomi Papadima-Sophocleous; Linda Bradley; Sylvie Thouësny. CALL communities and culture - short papers from EUROCALL 2016, Research-publishing.net, pp.277-283, 2016, 978-1908416-45-2. 10.14705/rpnet.2016.eurocall2016.575 . halshs-01422328

\section{HAL Id: halshs-01422328 \\ https://shs.hal.science/halshs-01422328}

Submitted on 25 Dec 2016

HAL is a multi-disciplinary open access archive for the deposit and dissemination of scientific research documents, whether they are published or not. The documents may come from teaching and research institutions in France or abroad, or from public or private research centers.
L'archive ouverte pluridisciplinaire HAL, est destinée au dépôt et à la diffusion de documents scientifiques de niveau recherche, publiés ou non, émanant des établissements d'enseignement et de recherche français ou étrangers, des laboratoires publics ou privés.

\section{(ㅇ)(1) $\$$}

Distributed under a Creative Commons Attribution - NonCommercial - NoDerivatives 44.0 


\title{
Exploring learners' perceptions of the use of digital letter games for language learning: the case of Magic Word
}

\author{
Mathieu Loiseau ${ }^{1}$, Cristiana Cervini ${ }^{2}$, Andrea Ceccherelli ${ }^{3}$, \\ Monica Masperi ${ }^{4}$, Paola Salomoni ${ }^{5}$, Marco Roccetti ${ }^{6}$, \\ Antonella Valva ${ }^{7}$, and Francesca Bianco ${ }^{8}$
}

\begin{abstract}
In this paper, we present two versions of a learning game developed respectively at the Grenoble Alpes and Bologna University. This research focuses on a digital game aimed at favouring the learners' playful attitude and harnessing it towards accuracy aspects of language learning (lexicon and morphology, here). The game, presently available for English, French and Italian, could be described as a letter game stemming from the archetypal example of Turoff's Boggle. Avatars of this game genre both exist as commercial off the shelf games and as learning games. We explain in this paper how our two versions respectively tackle two different aspects of language learning. We conducted an experiment in which all students tried both versions to study their perceptions of both games contrastively in order to prepare for the development of subsequent versions of the game.
\end{abstract}

Keywords: game based learning, Italian as a foreign language, learner perceptions, lexicon, morphology.

\footnotetext{
1. Université Grenoble Alpes - LIDILEM, Innovalangues, Saint Martin d'Hères, France; mathieu.loiseau@univ-grenoble-alpes.fr

2. Università di Bologna - LILEC Department, Innovalangues, Bologna, Italy; cristiana.cervini@unibo.it

3. Università di Bologna - LILEC Department, Bologna, Italy; andrea.ceccherelli@unibo.it

4. Université Grenoble Alpes - LIDILEM, Innovalangues, Saint Martin d'Hères, France; monica.masperi@univ-grenoble-alpes.fr

5. Università di Bologna - Department of Computer Science and Engineering, Bologna, Italy; paola.salomoni@unibo.it

6. Università di Bologna - Department of Computer Science and Engineering, Bologna, Italy; marco.roccetti@unibo.it

7. Università di Bologna - LILEC Department, Bologna, Italy; antonella.valva2@unibo.it

8. Università di Bologna - Innovalangues, Bologna, Italy; francesca.bianco6@studio.unibo.it

How to cite this article: Loiseau, M., Cervini, C., Ceccherelli, A., Masperi, M., Salomoni, P., Roccetti, M., Valva, A., \& Bianco, F. (2016). Exploring learners' perceptions of the use of digital letter games for language learning: the case of Magic Word. In S. Papadima-Sophocleous, L. Bradley \& S. Thouësny (Eds), CALL communities and culture - short papers from EUROCALL 2016 (pp. 277-283). Research-publishing.net. https://doi.org/10.14705/rpnet.2016.eurocall2016.575
} 


\section{Game based (accuracy) learning ${ }^{9}$}

Many researchers see various advantages in game based learning (e.g. Oblinger, 2004). Some see games as consistent with the central notion of tasks (Cornillie, Thorne, \& Desmet, 2012). Yet the emergence of a playful attitude, considered productive in games in terms of (language) learning (Silva, 2008), is far from being systematic in learning games. In the hope of favouring its emergence, we resort to the metaludic rules (pertaining to a game genre) (Silva, 1999) of successful and repeatable games (digital or board games, which do not rely on a plot).

Our research could be described as 'design based', which is inseparable from iterative development (Harvey \& Loiselle, 2009). To prepare for subsequent iterations, we implemented two versions of the same game with a view to comparing the responses of learners to both. Each version has its own pedagogical approach but both address accuracy - micro-operations and language correction - as opposed to fluency (Portine, 2013). The first prototype was conceived and implemented at the Grenoble Alpes University (Loiseau, Zampa, \& Rebourgeon, 2015), within the Innovalangues project (Masperi \& Quintin, 2014), while the second was developed by the University of Bologna within the context of the 'E-LOCAL for all' project (Ceccherelli \& Valva, 2016).

\section{The prototypes}

Despite adopting different points of view, both versions of our digital letter game, called Magic Word, are based on the same metaludic rules that could be exemplified by the well-known example of Boggle ${ }^{10}$, where the user is presented with a $4 \times 4$ letter grid and can create inflected forms ('example' and 'examples' are considered two separate words) using contiguous letters, in every direction, using each letter cell at most once per word form.

The Grenoble prototype was implemented in $2014^{11}$. Available in French, English and Italian, it aims at harnessing normative rules - rules adopted by advanced players of the game (Silva, 1999) - to work on morphological aspects of the language. It is inherent to the game, especially for languages with rich inflexion mechanisms, that the player should exhaustively seek all forms stemming from

9. Our approach is consistent across projects, this re-uses parts of Loiseau, Hallal, Ballot, and Gazidedja (2016, this volume) rather than artificially paraphrasing it, but also completes it.

10. Designed by Turoff in 1972, see https://en.wikipedia.org/wiki/Boggle.

11. http://gamer.innovalangues.net/magicword/ / https:/github.com/InnovaLangues/Magic-Word-game 
found words (Loiseau et al., 2015). In Figure 1, for instance, if both players found 'mia' ('my', fem. sing.), the player who realises that its masculine ('mio') and plural feminine ('mie') forms are also in the grid will have an advantage over the opponent. Even if a player finds a form by luck, the competitive nature of this version provides an incentive to infer the category of the word in order to see if the grid does not contain other forms. Games are played one-on-one (asynchronously) in three sets. While the lexical nature of the game is mainly addressed through the existence of a personal lexicon for each learner, called a 'wordbox', stemming mechanisms are at the core of the rules.

Figure 1. Screen captures of both versions of the game (left: Grenoble / right: Bologna)

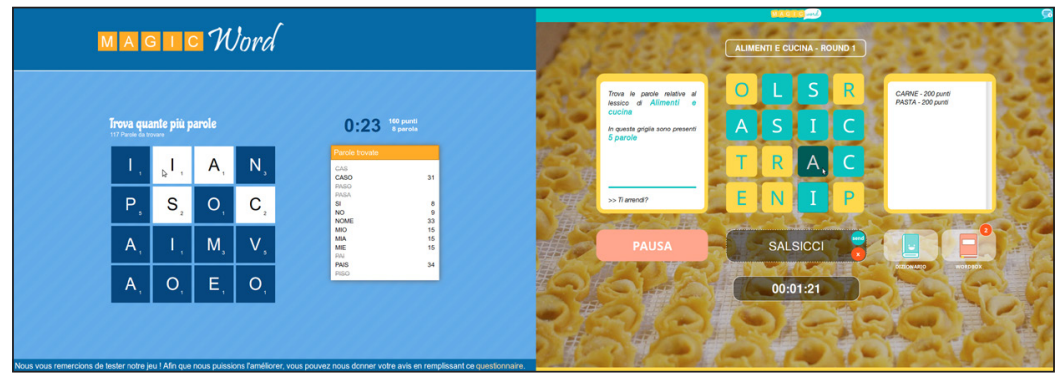

The Bologna prototype ${ }^{12}$, solely in Italian, is to be interfaced with the 'E-LOCAL for all' project. Dedicated to helping student mobility and multilingualism, the project proposes eight core units built around a main theme linked to a possible real-life situation (Ceccherelli \& Valva, 2016). This thematic progression calls for a focus on vocabulary that the Grenoble version could not provide. Creating grids containing certain forms is a complex algorithmic problem. This version provides a solution able to produce a grid containing a significant number of E-LOCAL terms (Roccetti et al., 2016). Each grid in this prototype has a specific cultural background concerning Italy and specifically Bologna; graphics were adapted through pictures linked to each theme to convey that cultural focus.

\section{Experiment protocol}

Following design based research principles, we took advantage of these two versions to gather learner reactions to each prototype's specificities: different 
learning objectives (morphology vs lexicon) sought after through different game structures (speed and competition vs completion of lexical puzzles), with different input modalities (sliding vs successive clicks) and layouts.

The experiment was conducted for Italian as a foreign language over 20 groups of learners from the Université Grenoble Alpes and the Università di Bologna (group levels A1 to C1). It took place in March and April 2016 during the classes of eight different teachers. The project and games were introduced briefly. Around 40 minutes were then left to the 148 learners ${ }^{13}$ surveyed to test both games and 20 minutes to fill out the questionnaires presented to them (in English, French or Italian). To make sure that results were not influenced by which game was presented first, some groups started with the Bologna version while others with Grenoble's. A third of the students (59) were given a self-assessing pre-test. Students were to tick the words they knew from a list. It meant to get an indication of their lexical knowledge, but also to see whether reading some words present in the Bologna grids before playing would help them solve the puzzles. Such short exposure to the games will not allow us to draw any conclusions concerning their learning outcomes (Girard, Ecalle, \& Magnan, 2013); we focused on the students' reactions and expectations.

\section{Results}

We are interested in the learners' perceptions of the game and their inclination to play them again. After the experiment, we asked them whether they would like to play (any) Magic Word during their Italian language class, nearly $85 \%$ of the students answered positively.

The students were also asked to answer on a four-level Likert scale various questions, including concerning their appreciation of the games (how much fun they had playing and whether they would like to play again) and if they felt they could learn while playing them. Considering the two upper levels of the Likert scale as positive outcomes, about $80 \%$ of the students found the Bologna version fun and more than $75 \%$ wanted to play it again, while more than $85 \%$ found the Grenoble version fun and $85 \%$ wanted to play it again.

Attributing a number (one to four) to every level of the scale allowed to perform inferential statistics ${ }^{14}$. The following results always use such data with questions

13. $75 \%$ female, $90+\%$ between $18 \& 24$ years old.

14. The tests performed were paired samples t-tests, Welch two samples t-tests, Pearson's Chi-squared test with Yates' continuity correction and Pearson's product-moment correlation (Norman, 2010). 
directly targeting each feature described. For instance, the differences above were significant (Fun: $t(147)=-4.3533, p<.001$; Play again: $t(147)=-3.5961, p<.001$ ), even though the students significantly preferred the graphics of the Bologna version (92.5\% favorable opinion for Bologna vs 83\% for Grenoble $-t(147)=3.2286$, $p<.005)$. This difference could be linked to the fact that $93 \%$ viewed competition positively (Grenoble) against 79\% appreciating being able to play without the pressure of a timer (Bologna).

The learners found the Bologna version slightly, yet significantly, more relevant for learning than the Grenoble version (75\% favorable opinion for Bologna vs $71 \%$ for Grenoble $(t(147)=2.5376, p<.05)$, thus echoing the teachers preference for the lexical dimension of the game.

Finally, results to the pre-test did not yield effect on other variables, taking it did not influence the players' achievements. However, its mere presence underlined the importance of the 'ludic context'; learners who were administered the tedious pretest (checking long lists of words) showed less inclination towards playing either game again (Reusing MW in class: $\chi^{2}(1)=4.0281, p<.05$; Play again - Grenoble: $t(92.5)=2.9759, p<.005$; Play again - Bologna: $t(102)=1.7607, p<.05)$.

\section{Discussion, future works and conclusion}

Our experiment, testing two versions of Magic Word, shows positive reception of both versions in terms of game characteristics and expected learning outcomes. Though the fact that the games were played for less than an hour should be taken into consideration when interpreting the results, this reception is encouraging. Learners display a certain preference for the Grenoble version, though the Bologna version is perceived as more likely to result in learning. We also know its rules are more favoured by teachers, which could be linked to the level of rules at which the 'learning' component is integrated (constitutive or even metaludic for lexicon vs normative for morphology). Thus, future versions of the game should (1) adapt the Bologna rules to introduce a competition element, and (2) make the normative rules of the Grenoble version more perceivable by beginner players.

Consequently, the algorithm conceived in Bologna is of the utmost importance for both institutions as it will facilitate the integration of the game in classes. Completing these results, a focus groups showed that teachers are more prone to using Magic Word for lexical acquisition. The algorithm thus opens doors for customisation of the content by teachers, one of their central needs (Hallal, 2015). 
Thanks to the open-source nature of both prototypes, a new version is being implemented in Grenoble. Though this work is mostly focused on the ludic structures, the response of the students who took the pre-test also underlines the influence of the ludic context on the reception of the game, highlighting Silva's (2008) point of view. Finally, it is worth mentioning that neither the proficiency level of the students, nor their gaming experience or gender yielded any significant difference in their appreciation of either game.

\section{Acknowledgements}

We would like to thank the Innovalangues and 'E-LOCAL for all' projects for allowing this research. We also thank all those who contributed to it (especially the upcoming version) including: Pauline Ballot, Racha Hallal, Virginie Zampa, Pauline Rebourgeon, Giacomo Mambelli, Christine Lutian, Maryam Nejat, David Graceffa, Richard Boualavong, Agnès Montaufier, Benjamin Abrial, Arnaud Bey and all the teachers and learners who tried it.

\section{References}

Ceccherelli, A., \& Valva, A. (2016). Fostering multilingualism and student mobility: the case of E-LOCAL for all. In C. Cervini (Ed.), Interdisciplinarità e apprendimento linguistico nei nuovi contesti formativi. L'apprendente di lingue tra tradizione e innovazione (pp. 21-39). Bologna: CeSLiC. https:doi.org/10.6092/unibo/amsacta/5069

Cornillie, F., Thorne, S. L., \& Desmet, P. (Eds). (2012), Digital games for language learning: challenges and opportunities. ReCALL special issue, 24(3), 243-256.

Girard, C., Ecalle, J., \& Magnan, A. (2013). Serious games as new educational tools: how effective are they? A meta-analysis of recent studies. Journal of Computer Assisted Learning, 29(3), 207-219. https://doi.org/10.1111/j.1365-2729.2012.00489.x

Hallal, R. (2015). La conception d'un jeu numérique pour l'apprentissage des langues Considérations théoriques et empiriques. Masters thesis. Université Stendhal Grenoble 3. http://dumas.ccsd.cnrs.fr/dumas-01236245

Harvey, S., \& Loiselle, J. (2009). Proposition d'un modèle de recherche développement. Recherches qualitatives, 28(2), 95-117.

Loiseau, M., Hallal, R., Ballot, P., \& Gazidedja, A. (2016). Game of Words: prototype of a digital game focusing on oral production (and comprehension) through asynchronous interaction. In S. Papadima-Sophocleous, L. Bradley \& S. Thouësny (Eds), CALL communities and culture - short papers from EUROCALL 2016 (pp. 284-289). Research-publishing.net. https://doi. org/10.14705/rpnet.2016.eurocall2016.576 
Loiseau, M., Zampa, V., \& Rebourgeon, P. (2015). Magic Word : premier jeu développé dans le cadre du projet Innovalangues. ALSIC, 18(2). https://doi.org/10.4000/alsic.2828

Masperi, M., \& Quintin, J.-J. (2014). L'innovation selon Innovalangues (E. D. Col, Ed.). Lingua e nuova didattica, 1, 6-14.

Norman, G. (2010). Likert scales, levels of measurement and the « laws » of statistics. Advances in Health Sciences Education, 15(5), 625-632. https://doi.org/10.1007/s10459-010-9222-y

Oblinger, D. G. (2004). The next generation of educational engagement. Journal of Interactive Media in Education, 2004(1), 10. https://doi.org/10.5334/2004-8-oblinger

Portine, H. (2013). L'ingénierie linguistique: des technologies au service d'une didactique intégrant la cognition ? In C. Ollivier \& L. Puren (Eds), Mutations technologiques, nouvelles pratiques sociales et didactique des langues (pp. 159-168). Clé International.

Roccetti, M., Salomoni, P., Loiseau, M., Masperi, M., Zampa, V., Ceccherelli, A., Cervini, C., \& Valva, A. (2016). On the design of a word game to enhance Italian language learning. Presented at the 2016 International Conference on Computing, Networking and Communications (ICNC 2016) - 12th IEEE International Workshop on Networking Issues in Multimedia Entertainment (NIME 2016), Kaui: IEEE Communications Society (pp. 1-5). http://dx.doi.org/10.1109/ICCNC.2016.7440546

Silva, H. (1999). Poétiques du jeu. La métaphore ludique dans la théorie et la critique littéraires françaises au XXe siècle. PhD thesis. Paris: Université Paris 3, Sorbonne Nouvelle. http:// lewebpedagogique.com/jeulangue/files/2011/01/PoetiquesLud.pdf

Silva, H. (2008). Le jeu en classe de langue. Techniques et pratiques de classe. Paris: CLE International. 


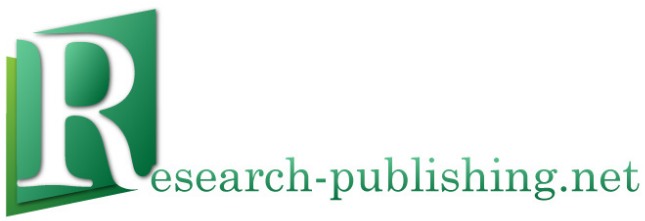

Published by Research-publishing.net, not-for-profit association Dublin, Ireland; Voillans, France, info@research-publishing.net

(C) 2016 by Editors (collective work)

(C) 2016 by Authors (individual work)

\section{CALL communities and culture - short papers from EUROCALL 2016 Edited by Salomi Papadima-Sophocleous, Linda Bradley, and Sylvie Thouësny}

Rights: All articles in this collection are published under the Attribution-NonCommercial -NoDerivatives 4.0 International (CC BY-NC-ND 4.0) licence. Under this licence, the contents are freely available online as PDF files (https://doi. org/10.14705/rpnet.2016.EUROCALL2016.9781908416445) for anybody to read, download, copy, and redistribute provided that the author(s), editorial team, and publisher are properly cited. Commercial use and derivative works are, however, not permitted.

\section{(9) $\Theta \Theta$}

Disclaimer: Research-publishing.net does not take any responsibility for the content of the pages written by the authors of this book. The authors have recognised that the work described was not published before, or that it is not under consideration for publication elsewhere. While the information in this book are believed to be true and accurate on the date of its going to press, neither the editorial team, nor the publisher can accept any legal responsibility for any errors or omissions that may be made. The publisher makes no warranty, expressed or implied, with respect to the material contained herein. While Research-publishing.net is committed to publishing works of integrity, the words are the authors' alone.

Trademark notice: product or corporate names may be trademarks or registered trademarks, and are used only for identification and explanation without intent to infringe.

Copyrighted material: every effort has been made by the editorial team to trace copyright holders and to obtain their permission for the use of copyrighted material in this book. In the event of errors or omissions, please notify the publisher of any corrections that will need to be incorporated in future editions of this book.

Typeset by Research-publishing.net

Cover design by (C) Easy Conferences, info@easyconferences.eu,www.easyconferences.eu

Cover layout by (c) Raphaël Savina (raphael@savina.net)

Photo "bridge" on cover by (C) Andriy Markov/Shutterstock

Photo "frog" on cover by (C) Fany Savina (fany.savina@gmail.com)

Fonts used are licensed under a SIL Open Font License

ISBN13: 978-1-908416-43-8 (Paperback - Print on demand, black and white)

Print on demand technology is a high-quality, innovative and ecological printing method; with which the book is never 'out of stock' or 'out of print'.

ISBN13: 978-1-908416-44-5 (Ebook, PDF, colour)

ISBN13: 978-1-908416-45-2 (Ebook, EPUB, colour)

Legal deposit, Ireland: The National Library of Ireland, The Library of Trinity College, The Library of the University of Limerick, The Library of Dublin City University, The Library of NUI Cork, The Library of NUI Maynooth, The Library of University College Dublin, The Library of NUI Galway.

Legal deposit, United Kingdom: The British Library.

British Library Cataloguing-in-Publication Data.

A cataloguing record for this book is available from the British Library.

Legal deposit, France: Bibliothèque Nationale de France - Dépôt légal: décembre 2016. 